\title{
Developing Entrepreneurship Culture among University Students in South-South, Nigeria
}

\author{
B. A. Akuegwu \\ Department of Educational Administration and Planning, University of Calabar, Calabar Nigeria \\ Email: basakuegwu@gmail.com \\ F. D. Nwi-ue \\ Department of General Studies, Rivers' State Polytechnic, Bori Nigeria
}

\section{Doi:10.5901/mjss.2016.v7n2s1p315}

\section{Abstract}

\begin{abstract}
Entrepreneurship has become very relevant in the light of the present challenges of unemployment among the youths in Nigeria. It is an antidote to joblessness and youth restiveness. For entrepreneurship to produce the desired result, it must have a culture, which needs to be developed. This survey-designed study investigated the developing of entrepreneurship culture for global relevance among university students in South-South Nigeria. Two research questions and two hypotheses were formulated to give direction to this investigation. Graduating students of regular programme in federal universities in SouthSouth constituted the population. Stratified random sampling technique was used in drawing 340 of them to form the sample size. An instrument called "Students' Entrepreneurship Culture Development Questionnaire (SECDQ)" constructed by the researchers was used for data collection. Data collected were analysed statistically using Descriptive Statistics (Mean Rating), Population t-test of single mean and Independent t-test statistical techniques. Findings showed that University of Benin had the highest inclination to develop entrepreneurship culture among students. University students had the propensity to develop their exposure to occupational experience most. University development of entrepreneurship culture among students is significantly low. Developing of entrepreneurship culture among university students is significantly influence by gender. It was therefore recommended that universities should exert more efforts in developing entrepreneurship culture among her students by making entrepreneurship education more practical oriented.
\end{abstract}

Keywords: Entrepreneurship culture, University students, Development, Education.

\section{Introduction}

University education in Nigeria presently is fast losing the glamour that describes it as an excellent avenue for acquiring the necessary skills, knowledge, values and attitude for solving the fundamental problems of life. This is because its products have been found incapable of contributing meaningfully towards the enhancement of societal wellbeing.

It is now a common knowledge that university students in Nigeria face many challenges upon graduation; chief among them is unemployment, which according to National Bureau of Statistics (2011) has grown from 12.3 percent in 2006 to 23.9 percent in 2011. It is more in 2015 judging from the progressive increase from 2006. The high rate of graduate unemployment with its attendant problems of poverty, instability and insecurity, is a worrisome phenomenon for a country in dire need of skilled manpower to achieve its developmental goals for a number of economic and social reasons. With this problem, the country loses in terms of the investments in providing them with education, while the students themselves remain unfulfilled since the opportunities for them to attain their life-long dreams become dimmed (Sanusi, 2012).

In the light of the present challenges of unemployment among Nigerian university graduates, entrepreneurship needs to be given serious consideration as the route to societal and global relevance. It is an antidote to joblessness, poverty, instability, insecurity and youth restiveness (Akuegwu \& Udida, 2008). However, for entrepreneurship to produce the desired result, it must have a culture which requires to be developed among university students through entrepreneurship education.

Entrepreneurship is a process of creating something new and valuable by devoting the necessary time, effort, energy and assuming the accompanying financial, psychic, social risks and receiving the resultant reward in monetary and personal satisfaction and independence (Chukwudi, 2005; Hisrich, Peters \& Shepherd, 2008). It is concerned with creating opportunities, meeting the needs of individuals, identifying gaps in one's immediate environment, community and 
society at large and bringing together resources in an innovative and profitable way to fill the gaps (Oni \& Olaleye, 2004).

Entrepreneurship education is a form of education that seeks to prepare people, especially youths, to be responsible, enterprising individuals who become entrepreneurs and entrepreneurial thinkers, and who contribute to economic development and sustainable communities (Consortium for Entrepreneurship Education, 2005). In the same vein, Schein (2009) views culture as a pattern of shared tacit assumptions that was learned by a group as it solved its problems of eternal adoption and internal integration that has worked well enough to be considered valid and therefore to be taught to new members as the correct way to perceive, think and feel in relation to those problems. It can also be referred to as attitudes and values which in the case of entrepreneurship may be linked with autonomy, creativity and a sense of responsibility (soft skills); entrepreneurial knowledge and skills and management competences which have to be acquired (hard skills). Therefore, entrepreneurship culture is a set of values, beliefs and attitudes commonly shared in a society which underpin the notion of any entrepreneurial way of life as being desirable and in turn support the pursuit of effective entrepreneurial behaviour by individuals or groups (Gibb, 1999). According to Chiesa and Chiaroni, (2005), entrepreneurship culture in a university setting would refer to students' attitude to expand beyond scientific side of research to go for commercialization of general knowledge. Such commercialization is reflected by establishing new ventures exploiting tacit knowledge obtained.

Entrepreneurship culture is inculcated through entrepreneurship education, which is aimed at changing students' state of behaviours and even intentions that makes them to understand entrepreneurship, to become entrepreneurial and to become an entrepreneur that finally resulted in the formation of new businesses as well as new job opportunities (Fayolle \& Gailly, 2005; Hannon, 2005; Venkatachalam \& Waqif, 2005). When students develop entrepreneurship culture, wealth creation is possible; jobs are created; individuals and collective wellbeing becomes a reality.

To this end, universities are constantly being challenged to prepare students to acquire entrepreneurial skills, knowledge and attitudes to enable them function effectively and be relevant in a dynamic, rapidly changing entrepreneurial and global environment. Thus, by creating entrepreneurial culture, universities are expected to influence students' decision to be favourable towards establishing business with their considerable influence factor on students. This is because universities are seedbeds of entrepreneurship to teach their students the way to think and behave entrepreneurially (Bygrave, 2004). In this regard, universities are tasked to create an entrepreneurially supportive environment that could encourage entrepreneurial activities, which would in turn help to develop an enterprise culture among students (Roffe, 1999). Buttressing this fact further, Babalola (2011) avers that regardless of the type of person a student might be, several school-related techniques can be used to drive students who are not naturally inclined to become entrepreneurs to develop and sustain interest in business. These include: exposure to occupational experience or industrial attachment, encouraging them to work independently, access to assistance to government and/or financial institutions, availability of technology and/or raw materials, knowledge of profit margin, allowing them to take personal responsibility, exposing them to success stories of entrepreneurs and exposing them to relevant skills or technical knowledge and know how.

However, despite the enviable positions of universities in inculcating and driving entrepreneurial culture among students, universities in South-South geographical zone in particular and Nigeria in general have not been able to connect themselves with industrialization through entrepreneurship. Some factors according to Onojetah (2011), responsible for this include the fact that universities are yet to produce a critical mass of individuals with the requisite generic skills to a level that will ensure their creative productivity. On the advantageous side, these generic skills are transversal in nature capable of ensuring that the rapid obsolescent of factual knowledge is taken care of by placing emphasis on tools and methods of knowing and doing and not on mere memorization and regurgitation (Ojo, 2007). Thus, university education is dysfunctional with inadequate curricula according to Central Bank of Nigeria (2005) in National Economic Empowerment and Development Strategy (NEEDS) document, lacking in utility (Etta, 2006) with regards to entrepreneurship, and so have deleterious effect on it (Onojetah, 2011).

In recognition of this anomaly, the then President of Nigeria, Chief Olusegun Obasanjo, in his quest to make Nigeria be among the top 20 leading economies in the world by 2020, mandated that all university students in Nigeria, regardless of their major, be exposed to entrepreneurship development study (Babalola, 2011). This gave birth to National Universities Commission's assemblage through a workshop of a team of experts mainly university lecturers to draw a curriculum for entrepreneurship education in 2003. The curriculum published in 2004 was implemented in 2007/2008 session with the introduction of entrepreneurship education in all universities in Nigeria as part of General Studies Programme, offered by second and third-year students of both regular and part-time programmes (Akuegwu \& Udida, 2008). The importance attached to entrepreneurship was further accentuated in the National Policy on Education (Federal Republic of Nigeria, 2013, p.27), that the goals of Tertiary Education shall be to: "promote and encourage scholarship, entrepreneurship and community service" amongst others, aimed at reducing skill shortages and enhancing 
self-reliance among youths. In spite of these developments, there is need to establish through empirical research the extent of developing entrepreneurship culture among university students for global relevance. It is on this basis that this study is being conducted.

\section{Statement of the Problem}

In Nigeria, provision is made for the study of entrepreneurship as a compulsory course at the General Studies (GSS) level for all second and third-year students in universities. In addition, universities, those in south-south inclusive, have set up entrepreneurship development centres as part of policies aimed at making entrepreneurship education create significant impact on students by developing entrepreneurship culture among them whereby they are turned into job creators instead of seekers with the attendant creative thinking and practical skills to produce and market products. However, the teaching of this course has remained at best theoretical presentation of course materials and concepts, with little or no emphasis on practical aspects. Even at that, the requisite manpower, funding, learning environment and infrastructure needed to create and develop entrepreneurship culture through this course are lacking. Could these be the reason for hundreds of thousands of university graduates remaining jobless many years after their graduation? While studies have been carried out on entrepreneurship behaviours or attitudes and job creation or self-reliance among students, none has been specifically targeted at developing entrepreneurship culture among university students, particularly in South-South geopolitical zone of Nigeria. It is the quest to provide answers to these issues that fired the zeal to undertake this study.

\section{Research Questions}

1. Which university has the highest inclination to develop entrepreneurship culture among regular programme students?

2. Which of the entrepreneurship culture variables do university regular programme students have the propensity to develop most?

\section{Hypotheses}

1. Developing entrepreneurship culture among university regular programme students is not significantly low

2. Developing entrepreneurship culture among university regular programme students is not significantly influenced by gender.

\section{Literature Review}

A study conducted by Wong (2011) found that entrepreneurship culture is composed of shared tacit assumptions about autonomy, innovativeness, risk taking, pro-activeness and competitive aggressiveness. It is when these assumptions are favourable and positive that students can develop entrepreneurship culture.

Mahlberg (1996) stated that universities have a key role to play in promoting entrepreneurship since educational institutions are ideally considered the place in shaping entrepreneurship cultures and aspirations among students while they are studying to survive in today's robust business milieu (Autio, Keeley, Klofsten \& Ulfstedt, 1997; Landstrom, 2005).

There is an articulation by employers of labour of the need for graduates to be equipped with a range of entrepreneurship skills with foci upon creativity, capacity for innovation, networking relationship management and risktaking (Moreland, 2007). This underscores the importance of educational programmes of universities to be purely geared towards developing entrepreneurship culture. Such programmes should have the goal of nurturing some attitudes and the overall entrepreneurial intention and that inspiration which is a construct with an emotional element, considered as the most influential benefits of entrepreneurship (Frolova, 2010). Similarly, European Commission (European Union, 2006) has in a number of studies called for the development of the entrepreneurial mindset in the student population. Evidence also abounds that the importance of entrepreneurship skills to future employment is shared by the students themselves (Coaldrake, 2001), and that universities are not seen to be fully equipped to meet this need (Coaldrake, 2001; Durham University Centre for Entrepreneurial Learning, 2009).

Autio et al (1997) studied entrepreneurial intentions of technology and science students across four countries and consistently concluded that university teaching environments are the most influential factors that affect students' perceptions towards entrepreneurial career and entrepreneurial convictions. This calls for presenting a positive image of 
entrepreneurship as career option to draw students' attention by providing the resources and other facilities available to them. The reason for this is that students' preferences towards career are easily influenced by the environmental conditions in which they are interacting with as they are young and always looking for appropriate models (Keat, Selvarajah \& Meyer, 2011; Gnyawali \& Fogel, 1994; Fayolle \& Degeorge, 2006).

Chiaha, Eze and Agu in Chiaha and Agu (2008) found in their studies that entrepreneurship education can make students more entrepreneurial by causing core traits like diligence and hard-work, confidence, risk-taking, decision making, interpersonal skills, leadership skills and goal getting skills to improve. This means that even if one lacks interest in entrepreneurial activities, the same can develop entrepreneurship culture having been exposed to the education.

Akuegwu and Udida (2008) found that university students' orientation towards entrepreneurial studies is significantly dependent on gender, while the outcome of Chiaha and Agu's (2008) study showed that entrepreneurship education makes individual to become more entrepreneurial irrespective of their gender or educational background. These imply that entrepreneurship education can produce different set of results on students depending on the area of study and the prevailing economic and entrepreneurship aspirations.

\section{Research Methods}

The setting for this research study is south-south geopolitical zone of Nigeria which has six states, famous for its huge mineral deposits notably crude oil. This zone is blessed with 13 public universities - 6 federal and 7 state-owned. The 6 Federal Universities provided the focus in which 4 of them were randomly drawn for use in this study.

The design adopted for this study was survey, while the population was constituted by graduating (final year) students of regular programme who were 3404 in number. The focus on this category of students was because, being at the exit point of their university education programme, they will soon graduate to face realities in the labour market, where they are expected to put into use the entrepreneurship culture they have developed by creating jobs for themselves. The sample comprised 340 of them drawn using stratified random sampling technique. A breakdown of the sample showed that 85 graduating (final year) students of regular programme were drawn from each of the 4 Federal Universities studied. The sampling ensured equal representation of male and female students - 170 each. However, due to the lopsided nature (odd-numbered) of the sample, 43 males and 42 females each were selected from 2 universities, while 43 females and 42 males were selected from the remaining 2 universities. Names of universities and gender provided the basis for stratification.

Data collection was carried out with a researchers-developed instrument called "Students' Entrepreneurship Culture Development Questionnaire (SECDQ)", made up of two sections - A and B. Section A contained 2 demographic variables namely name of institution and gender, while section B arranged on a 5-point rating scale had 32 items, 4 of which measured each of the 8 variables isolated for this study. These include: Exposure to Occupational Experience, Encouragement to Work Independently, Access to Governmental/Financial Institutions' Assistance, Availability of Raw Materials, Knowledge of Profit Margin, Opportunity to Display Personal Responsibility, Exposure to Success Stories of Entrepreneurs and Exposure to Technical Knowledge. These variables were adopted from Babalola (2011) and modified for use in executing this study. Experts in entrepreneurship education, and measurement and evaluation conducted the face validity of the instrument. The trial test carried out with Cronbach Coefficient Alpha, yielded coefficients ranging from .79 to .93 , which is an indication that the instrument was reliable for use to achieve the goal of this study.

The administration of the instrument was carried out by the researchers, with the help of 4 research assistants trained purely for data collection in universities where the researchers were unable to cover by themselves. This measure gave a 100 percent returns rate of the instrument.

Statistical analysis of the data collected was carried out with Descriptive Statistics (Mean Rating), Population t-test of single mean and Independent t-test. Summaries of the results were presented in tables.

\section{Results}

\subsection{Research Questions}

1. Which university has the highest inclination to develop entrepreneurship culture among regular programme students? Descriptive statistics (Mean Rating) is used to provide answer to this question. Summaries of the results are presented in table 1. 
Table 1: State of the Art Description of Universities' Inclination towards Developing Entrepreneurship Culture among Regular Programme Students.

\begin{tabular}{|c|c|c|c|c|c|c|c|c|}
\hline \multicolumn{9}{|c|}{$\mathrm{N}=340$} \\
\hline \multicolumn{9}{|c|}{ Universities } \\
\hline & \multicolumn{2}{|c|}{ UniBen } & \multicolumn{2}{|c|}{ UniCal } & \multicolumn{2}{|c|}{ UniPort } & \multicolumn{2}{|c|}{ UniUyo } \\
\hline Variables & $\overline{\mathrm{X}}$ & SD & $\overline{\mathrm{X}}$ & SD & $\overline{\mathrm{X}}$ & SD & $\overline{\mathrm{X}}$ & SD \\
\hline $\begin{array}{l}\text { Exposure to Occupational } \\
\text { Experience }\end{array}$ & 12.96 & 4.52 & 12.54 & 3.21 & 12.29 & 2.43 & 12.53 & 3.03 \\
\hline $\begin{array}{l}\text { Encouragement to Work } \\
\text { Independently }\end{array}$ & 12.44 & 3.86 & 11.65 & 2.91 & 9.63 & 2.93 & 10.45 & 2.94 \\
\hline $\begin{array}{l}\text { Exposure to Access to } \\
\text { Govemmental /Financial } \\
\text { Institutions'Assistance }\end{array}$ & 12.79 & 4.15 & 11.91 & 3.24 & 11.36 & 3.20 & 10.68 & 3.16 \\
\hline $\begin{array}{l}\text { Exposure to Availability } \\
\text { of Raw Materials }\end{array}$ & 12.09 & 3.69 & 11.40 & 3.19 & 12.13 & 3.27 & 11.36 & 3.06 \\
\hline $\begin{array}{l}\text { Exposure to Knowledge } \\
\text { of Profit Margin }\end{array}$ & 12.16 & 3.89 & 11.79 & 4.08 & 11.53 & 3.68 & 11.72 & 2.59 \\
\hline $\begin{array}{l}\text { Opportunity to Display } \\
\text { Personal Responsibility }\end{array}$ & 13.11 & 3.65 & 13.58 & 3.25 & 11.04 & 3.76 & 12.49 & 3.25 \\
\hline $\begin{array}{l}\text { Exposure to Success } \\
\text { Stories of Entrepreneurs }\end{array}$ & 13.54 & 3.46 & 13.49 & 2.74 & 12.28 & 3.26 & 12.69 & 3.25 \\
\hline $\begin{array}{l}\text { Exposure to Technical } \\
\text { Knowledge }\end{array}$ & 11.41 & 3.47 & 13.31 & 3.10 & 13.29 & 2.89 & 12.41 & 3.05 \\
\hline Grand Mean $(\widehat{x})$ & 12.56 & 3.84 & 12.46 & 3.22 & 11.69 & 3.18 & 11.79 & 3.04 \\
\hline
\end{tabular}

Summaries of this result displayed in table 1 revealed that University of Benin had the highest mean $(\overline{\mathrm{x}}=$ 12.56), followed by University of Calabar $(\bar{x}=12.46)$, University of Uyo $(\bar{x}=11.79)$ and University of Port Harcourt $(\bar{x}=11.69)$. This means that University of Benin had the highest inclination to develop entrepreneurship culture among her regular programme students.

2. Which of the entrepreneurship culture variables do university regular programme students have the propensity to develop most? Descriptive statistics (Mean Rating) is used to provide answer to this question. Summaries of the results are presented in table 2 .

Table 2: Mean $(\overline{\mathrm{x}})$ and Standard Deviation (SD) of University Regular Programme Students' Propensity to Develop Entrepreneurship Culture.

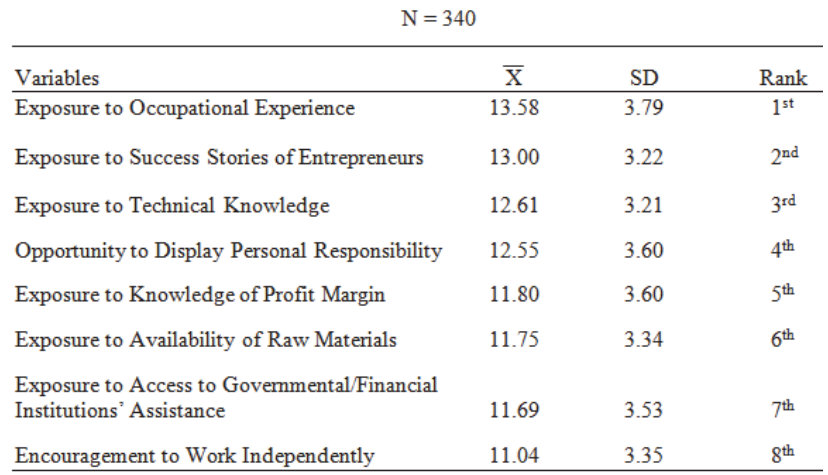

Summaries of the results presented in table 2 indicated that university regular programme students had the propensity to develop their exposure to occupational experience most, following its highest mean value $(\overline{\mathrm{x}}=$ 13.58). Second is their exposure to success stories of entrepreneurs $(\bar{x}=13.00)$, followed by their exposure to technical knowledge in the third position $(\bar{x}=12.61)$. Opportunity to display personal responsibility is in fourth position $(\bar{x}=12.55)$, with exposure to knowledge of profit margin in the fifth position $(\bar{x}=11.80)$, exposure to 
availability of raw materials is in the sixth position $(\bar{x}=11.75)$, while exposure to access to governmental/financial institutions' assistance took the seventh position $(\bar{x}=11.69)$, Last on the list is their encouragement to work independently with mean value $(\bar{x}=11.04)$.

\subsection{Hypotheses}

1. Developing entrepreneurship culture among university regular programme students is significantly low. The only variable in this hypothesis is developing entrepreneurship culture among university regular programme students. Population t-test of single mean is used to analyse data collected statistically. Summaries of the results are presented in table 3 .

Table 3: Summaries of Population t-test of Single Mean Analysis of Universities' Developing of Entrepreneurship Culture among Regular Programme Students

\begin{tabular}{|c|c|c|c|c|}
\hline \multicolumn{5}{|c|}{$\mathrm{N}=340$} \\
\hline Variables & $\begin{array}{l}\text { Observed } \\
\text { Mean } \overline{(\mathrm{X})}\end{array}$ & $\begin{array}{l}\text { Assumed } \\
\text { Mean }(\mu)\end{array}$ & SD & t-value \\
\hline Exposure to Occupational Experience & 13.58 & 12.00 & 3.79 & $66.098^{*}$ \\
\hline Encouragement to Work Independently & 11.04 & 12.00 & 3.35 & $-60.749^{*}$ \\
\hline $\begin{array}{l}\text { Exposure to Access to Govemmental/ } \\
\text { Financial Institutions' Assistance }\end{array}$ & 11.69 & 12.00 & 3.53 & $-61.060^{*}$ \\
\hline Exposure to Availability of Raw Materials & 11.75 & 12.00 & 3.34 & $-65.298^{*}$ \\
\hline Exposure to Knowledge of Profit Margin & 11.80 & 12.00 & 3.60 & $-60.474^{*}$ \\
\hline $\begin{array}{l}\text { Opportunity to Display Personal } \\
\text { Responsibility }\end{array}$ & 12.55 & 12.00 & 3.60 & $64.335^{*}$ \\
\hline $\begin{array}{l}\text { Exposure to Success Stories of } \\
\text { Entrepreneurs }\end{array}$ & 13.00 & 12.00 & 3.22 & $74.459^{*}$ \\
\hline Exposure to Technical Knowledge & 12.61 & 12.00 & 3.21 & $72.307^{*}$ \\
\hline
\end{tabular}

Summaries of the results presented in table 3 revealed that the calculated t-values obtained were found to be higher than the critical t-value of 1.966 at .05 alpha level of significance and 339 degrees of freedom. In specific terms, the calculated $t$-values were as follows: Exposure to Occupational Experience $(t=66.098$, $p<.05)$, Encouragement to Work Independently ( $t=-60.749, \quad p<.05)$, Exposure to Access to Governmental/Financial Institutions' Assistance ( $t=-61.060, p<.05)$, Exposure to Availability of Raw Materials $(t=-65.298, p<.05)$, Exposure to Knowledge of Profit Margin $(t=-60.474, p<.05)$, Opportunity to Display Personal Responsibility ( $t=64.335, p<.05)$, Exposure to Success Stories of Entrepreneurs $(t=74.459, p<.05)$ and Exposure to Technical Knowledge $(t=72.307, p<.05)$. With these results, the null hypothesis was rejected. It was therefore found that universities' developing of entrepreneurship culture among regular programme students is significantly low.

A further examination of the results indicated that the observed mean $(\bar{x})$ universities' developing of entrepreneurship culture among regular programme students were found to be higher than the assumed mean of 12.00 in four of the variables, whereas in the remaining four, it was lower. Statistical comparison of these observed mean values and the assumed mean value of 12.00 using Population t-test of single mean gave positive and negative t-values. This means that universities' developing of entrepreneurship culture among her regular programme students is significantly low.

2. Developing of entrepreneurship culture among university regular programme students is not significantly influenced by gender. The independent variable is gender, while developing of entrepreneurship culture among regular programme students is the dependent variable. Independent t-test statistical analysis is used to compare the mean score of gender (male and female students) in their developing of entrepreneurship culture. Summaries of the results are presented in table 4. 
Table 4: Summaries of Independent t-test Statistical Analysis of the Influence of Gender on Developing of Entrepreneurship Culture among University Regular Programme Students.

\begin{tabular}{lccccc}
\hline & \multicolumn{2}{c}{ Male } & \multicolumn{2}{c}{ Female } \\
& \multicolumn{1}{c}{$\mathrm{N}=170$} & \multicolumn{2}{c}{$\mathrm{N}=170$} & \\
Variables & $\mathrm{X}$ & $\mathrm{SD}$ & $\mathrm{X}$ & $\mathrm{SD}$ & t-value \\
\hline Exposure to Occupational Experience & 14.75 & 4.30 & 12.41 & 2.74 & $6.000^{*}$ \\
Encouragement to Work Independently & 12.04 & 3.43 & 10.04 & 2.95 & $5.757^{*}$ \\
Exposure to Access to Government/ & & & & & \\
Financial Institutions' Assistance & 12.34 & 3.74 & 11.02 & 3.18 & $3.515^{*}$ \\
Exposure to Availability of Raw Materials & 11.76 & 3.46 & 11.75 & 3.18 & 0.028 \\
Exposure to Knowledge of Profit Margin & 11.98 & 3.98 & 11.62 & 3.18 & 0.904 \\
Opportunity to Display Personal & & & & & \\
Responsibility & 13.34 & 3.45 & 11.76 & 3.58 & $4.135^{*}$ \\
Exposure to Success Stories of & & & & & \\
Entrepreneurs & 13.52 & 3.11 & 12.49 & 3.25 & $2.981^{*}$ \\
Exposure to Technical Knowledge & 12.36 & 3.41 & 12.85 & 2.99 & -1.419 \\
\hline *Significant at .05; df = 338; Critical t-value $=1.966$ & & & &
\end{tabular}

Summaries of the results displayed in table 4 disclosed that the calculated t-values were found to be higher in five of the variables, while in the remaining three, it was lower at .05 alpha level of significance and 338 degrees of freedom. Specifically, the higher calculated t-values were obtained on the following variables: Exposure to occupational experience $(t=6.000, p<.05)$, Encouragement to work independently $(t=5.757$, $p<.05)$, Exposure to access to government/financial institutions' assistance $(t=3.515, p<.05)$, Opportunity to display personal responsibility $(t=4.135, p<.05)$ and Exposure to success stories of entrepreneurs $(t=2.981$, $p<.05)$. With these results, the null hypothesis was rejected and so, developing of entrepreneurship culture among university students is significantly influenced by gender among these variables. In contrast, the calculated t-values were found to be lower in three variables namely: Exposure to availability of raw materials $(t=0.028, p<.05)$, Exposure to knowledge of profit margin $(t=0.904, p<.05)$ and Exposure to technical knowledge $(t=-1.419, p<.05)$. The null hypothesis was not rejected with these results. It therefore means that developing of entrepreneurship culture among university regular programme students is not significantly influenced by gender among these variables.

A further examination of these results revealed that male university regular programme students had higher mean $(\bar{x})$ values in seven of the variables studied than their female counterparts, while in one variable, female university regular programme students had on edge over their male counterparts. This means that male university regular programme students develop entrepreneurship culture better than their female counterparts.

\section{Discussion of Results}

Summaries of the results of research question one revealed that university of Benin had the highest inclination to develop entrepreneurship culture among students, judging from her highest mean value of $(\bar{x}=12.56)$, followed by University of Calabar $(\bar{x}=12.46)$, University of Uyo $(\bar{x}=11.79)$ and lastly University of Port Harcourt with $(\bar{x}=11.69)$. This means that among the four Federal Universities studied, University of Benin has the highest likelihood or desire to develop entrepreneurship culture on her graduating (final year) regular programme students.

A plausible explanation for this finding hinges on the fact that University of Benin is among the first generation universities in Nigeria, while the rest three are second generation. It therefore follows that its position made it to be sending students into the labour market through graduation before others, and as such, it started feeling the pangs of graduate unemployment before other three universities studied. In corroboration to this articulation, University of Benin established Entrepreneurship Development Centre in 2002/2003 academic session before National Universities Commission (NUC) came up with a curriculum on Entrepreneurship Education in 2004. Other universities established theirs as university-wide centres after this date (2004). By implication, therefore, University of Benin, having started Entrepreneurship Programme before others is likely to have edge over them in developing entrepreneurship culture among her regular programme students.

Surprisingly, University of Port Harcourt sited on a more cosmopolitan town (Port Harcourt) than others took the 
last position. It therefore follows that the nature of the town universities are sited in do not influence the developing of entrepreneurship culture among regular programme students in such universities.

Summaries of the results of research question two disclosed that university regular programme students had the highest propensity to develop their exposure to occupational experience most than any other entrepreneurship culture variables studied. This means that among the eight variables of entrepreneurship culture studied, exposure to occupational experience attracts them most, followed by exposure to success stories of entrepreneurs, and lastly, encouragement to work independently.

The reason for this finding might be that as students are made to understudy other entrepreneurs through Students' Industrial Work Experience Scheme (SIWES), they are likely to acquire the necessary experience and exposure before venturing into their own business. These place them on a better pedestal to be familiar with the nature, terrain, demands and rigours of such entrepreneurial ventures, and as such are equipped with the wherewithal to succeed in facing new challenges that would bring improvement to their lives and society. Closely associated with this is their exposure to success stories of entrepreneurs, which ranked second. This means that by being exposed to success stories of entrepreneurs, university students get motivated to be like those entrepreneurs, and hence develop the preference for entrepreneurial ventures. From this finding, it shows that what drives the propensity of university regular programme students to develop entrepreneurship culture is what they can learn from others, and not their personal efforts and experience.

The results of hypothesis one indicated that universities developing of entrepreneurship culture among her regular programme students is significantly low. That is, the developing of entrepreneurship culture by universities on their regular programme students has not achieved tangible results. By implication, the universities have not been able to evolve tangible efforts to develop entrepreneurship culture among their regular programme students.

The reason for this finding can be attributed to the inability of universities to place entrepreneurship education in a context that emphasizes practical skills in setting up and managing a business. Rather, the education has been more of theoretical presentation of facts and knowledge. Under this arrangement, there is no way a student, who should be regarded as a potential entrepreneur can adequately grasp all that it takes to develop entrepreneurship culture, and so the required orientation and attitudinal mindset towards entrepreneurship will continue to elude them.

Low developing of entrepreneurship culture by universities among her regular programme students accounts for a large number of graduates remaining jobless years after their graduation. Furthermore, this low developing of entrepreneurship culture is fallout of universities' inability to engage qualified personnel in entrepreneurship education and procure materials and equipment necessary to back up the education. This inability is occasional by poor funding which universities have been operating under for a long time in Nigeria. Incidentally, this issue of poor funding has been at the centre of disputes between university workers' union and Federal Government of Nigeria, which has always culminated into strike actions by the former. Ordinarily, lack of funds is followed by lack of sufficient personnel and material. A delicious and palatable dish is a product of money, and so, developing entrepreneurship culture that can transform students into venture creators must be backed up by adequate funding.

From this articulation, it is evident that universities have not been fully equipped to meet the need for entrepreneurship culture among students (Coaldrake, 2001; Durham University Centre for Entrepreneurial Learning, 2009). No doubt, they have been given the mandate to play leading role in inculcating students with the entrepreneurship knowledge and skills that will be useful in their future career endeavours (Nurmi \& Paasio, 2007). Therefore, there is need to properly equip them to deliver on this mandate.

Summaries of the results of hypothesis two showed that developing entrepreneurship culture among university regular programme students is significantly influenced by gender. That is, the measures students are exposed to in universities to develop their entrepreneurship culture and the way they respond is dependent on their gender. Thus, the way male students respond to their development of entrepreneurship culture in universities is not the same with their female counterparts. Similarly, this finding indicated a significant difference between male and female university regular programme students in their developing of entrepreneurship culture with the males having an edge over their female counterparts. This is attested to by the higher mean $(\bar{x})$ values obtained by the male students in seven of the eight variables studied, as against the female students' one.

The reason for this finding may not be unconnected with the position of males in the families and society as the bread winners who are expected to cater for the needs of others. This therefore places on them the mandate to work harder to meet the family and society expectations. As such, the findings that male university students differed significantly from their female counterparts in their developing of entrepreneurship culture is not surprising. With this finding, male students have the tendency to be better and relevant entrepreneurship- wise than their female counterparts.

This finding is consistent with that of Akuegwu and Udida (2008) that male and female university students differed 
significantly in their orientation towards entrepreneurial studies, with males having the upper hand, which is better orientation. With male students having better orientation, it is likely to be translated to developing entrepreneurship culture more than the female students. In contrast, the outcome of Chiaha and Agu's (2008) study showed that entrepreneurship education makes individuals to become more entrepreneurial irrespective of their gender or educational background. It therefore follows that what develops entrepreneurship culture is entrepreneurship education and not necessarily gender.

\section{Conclusion}

Following the finding from this study, the conclusion drawn is that University of Benin has the highest inclination to develop entrepreneurship culture among graduating regular programme students. University regular programme students have the propensity to develop their exposure to occupational experience most, an indication that they are favourably disposed towards this aspect of entrepreneurship culture most. University development of entrepreneurship culture among her regular programme students is significantly low. Developing entrepreneurship culture among university regular programme students is significantly influenced by gender, with males tilting towards developing entrepreneurship culture more than the females. With low development of entrepreneurship culture among regular programme students by universities generally, some still have the inclination to develop entrepreneurship culture among their regular programme students better than others.

\section{Recommendations}

These recommendations are put forward, following the results from this study.

1. Universities should exert more efforts in developing entrepreneurship culture by making entrepreneurship education more practical oriented. Through this measure, students may be exposed to firsthand knowledge about setting up and managing new ventures, which may go a long way to make students job creators and not seekers. More importantly, by encouraging the developing of entrepreneurship culture, universities may be working towards reducing unemployment among her graduates and its associated problems.

2. Female university students should be encouraged to develop entrepreneurship culture. This may enable them to be economically independent, and compete favourably with their male counterparts. More especially, female students should be exposed to entrepreneurship practices with a viewing to arousing their interest on it.

\section{References}

Akuegwu, B. A. \& Udida, L. A. (2008). University students' orientation towards entrepreneurial studies and its management implications for sustainable development: Nigerian Journal of Educational Administration and Planning, 8(1), 141 - 152.

Autio, E., Keeley, R. H., Klofsten, M. \& Ulfstedt, T. (1997). Entrepreneurial intent among students: Testing an intent model in Asia, Scandinavia and USA. Frontiers of Entrepreneurship Research 17. Wellesley: Babson College/Kauffman Entrepreneurship Research Conference Centre for Entrepreneurial Studies, Babson College.

Babalola, J. B. (2011). Eyeing sustainable development: Entrepreneurial climate must change in Nigerian Universities. In E. A. Arubayi, E. A. Akpotu, \& E. P. Oghurbu, (eds), Education and training for entrepreneurship: A book of readings (pp. 8 - 19) Abraka: University Printing Press

Bygrave, W. D. Z. A. (Ed.) (2004). The portable MBA in entrepreneurship: The entrepreneurial process. New Jersey: John Wiley \& Sons, Inc.

Central Bank of Nigeria (2005). National economic empowerment and development strategy (NEEDS). Abuja: National Planning Commission

Chiaha, G. T. U. \& Agu, R. A. (2008). Assessment of the influence of entrepreneurship education for sustainable development in Nigeria: Function of educational background and gender. Nigerian Journal of Educational Administration and Planning, 8(1), 245 - 257

Chiesa,V. \& Chiaroni, D. (2005). Industrial clusters in biotechnology: Driving forces, development processes and management practices. London, UK: Imperial College Press

Chukwudi, O. W. (2005). The entrepreneur: Challenges, coping strategies and implications for entrepreneurship education. A Lead Paper presented at the $6^{\text {th }}$ Annual Conference of Hope Economic Research Association of Nigeria (HERAN) on the $8^{\text {th }}$ September

Coaldrake, P. (2001). Responding to changing student expectations. Higher Education Management, 13(2), 75 - 93

Consortium for Entrepreneurship Education (2005). Criteria for youth entrepreneurship education. Retrieved from http://www.entreed.org

Durham University Centre for Entrepreneurial Learning (2009) A study of graduate aspirations to and understanding of entrepreneurial 
behaviour. Durham UK

Ettah, B. (2006). 21st Century strategic studies and research on effective dynamics and educational revolution. Bamenda: A Nation Builders International Publication.

European Union (2006). Entrepreneurship education in Europe: Fostering entrepreneurial mindsets through education and learning. Final proceedings of the Oslo Conference 27-27 October, European Commission.

Fayolle, A. \& Degeorge, J. M. (2006). Attitudes, intentions and behaviour: New approaches to evaluating entrepreneurship education. In A. K. Fayolle, \& H. Cheltenham (Eds.), International entrepreneurship education: Issues and newness (pp. 320 - 336). United Kingdom: Edward Elgar Publishing.

Fayolle, A. G. \& Gailly, B. (2005). Using the theory of planned behaviour to assess entrepreneurship teaching programmes, Centre for Research in Change, Innovation and Strategy: 1-18.

Federal Republic of Nigeria (2013). National policy on education (6 $6^{\text {th }}$ ed.). Lagos: Nigerian

Educational Research and Development Council.

Frolova, P. (2010). Entrepreneurial culture in innovative bioclusters: Towards a success factors model. M. A. Thesis, University of Twente, The Netherlands

Gibb, A. (1999). Creating an entrepreneurial culture in support of SMEs. Small Enterprise Development, 10(4), 27 - 38.

Gnyawali, D. R. \& Fogel, D. S. (1994). Environments for entrepreneurship development: key dimensions and research implications. Entrepreneurship Theory and Practice 18(4), 43 - 62.

Hannon, P. D. (2005). The journey from student to entrepreneur: A review of the existing research into graduate entrepreneurship. United Kingdom: National Council for Graduate Entrepreneurship.

Hisrich, R. D., Peters, M. P. \& Shepherd, D. A. (2008). Entrepreneurship. New Delhi: Mc Graw-Hill Publishing Company

Keat, O. Y., Selvarajah, C. \& Meyer, D. (2011). Inclination towards entrepreneurship among university students: An empirical study of Malaysian University Students. International Journal of Business and Social Science, 2(4), $206-220$

Landstrom, H. (2005). Pioneers in entrepreneurship and small business research. New York: Springer Science+Business Media.

Mahlberg, T. (1996). Evaluating secondary school and college level entrepreneurial education - pilot testing questionnaire. The internationalising entrepreneurship education and training conference, Arnhem/University of Nijmegen, The Netherlands.

Moreland, N. (2007). Entrepreneurship and higher education: An employability perspective. United Kingdom: The Higher Education Academy.

National Bureau of Statistics (2011). Annual abstract of statistics. Abuja: National Bureau of Statistics

Nurmi, P. \& Paasio, K. (2007). Entrepreneurship in Finnish universities. Education + Training, 49(1), 56 - 65.

Ojo, G. O. (2007). Higher education in Nigeria for sustainable economic development. In J. B. Babalola, G. O. Akpa, A. O. Ayeni \& S. O. Adedeji (Eds.), Access, equity and quality in higher education (pp. 33 - 40). Ibadan: NAEAP

Oni, E. D. \& Olaleye, S. S. (2004). A new perspective on entrepreneurship. Ibadan: Ejon Publishers

Onojetah, S. O. (2011). Reforms in tertiary education and training for entrepreneurship and sustainable development in Nigeria. In E. A. Arubayi, E. A. Akpotu, \& E. P. Oghurbu, (eds), Education and training for entrepreneurship: A book of readings (pp. 8 - 19) Abraka: University Printing Press

Roffe, I. (1999). Transforming graduates, transforming firms. Education + Training, 41(4), 194 - 201.

Sanusi, L. S. (2012). Employment skills, values, opportunities and challenges of university graduating students. Special lecture delivered at university of Calabar, November 14.

Schein, E. H. (2009). The corporate culture survival guide. San Francisco, CA: Jossey-Bass.

Venkatachalam, V. B. \& A. A. Waqif (2005). Outlook on integrating entrepreneurship in management education in India. Decision, 32(2), $57-71$.

Wong, M. A. (2011). The evolution of entrepreneurial culture: Two competing perspectives. USASBE Proceedings, 2011. Retrieved from http://www.sbaer.uca.edu/research/USASBE/2011/paperID89.pdf. 